\title{
THE IMPACT OF CORPORATE GOVERNANCE ON FIRM'S FINANCIAL DISTRESS: A CASE STUDY OF UK BASED FIRMS
}

\author{
Naveed Khan ${ }^{1}$ iD Dongmin Kong ${ }^{2}$ \\ ${ }^{1} \mathrm{Ph} . \mathrm{D}$. Scholar School of Finance Zhongnan, University of Economics and Law, Wuhan, China. \\ ${ }^{2}$ Professor, School of finance Zhongnan, University of Economics and Law, Wuhan, China
}

\section{ARTICLE INFO \\ Received: 11 December 2021 Revised: 18 February 2022 Accepted: 19 February 2022 \\ Keywords: Corporate Governance Practices, Board Independence, Institutional Ownership, Shareholder's Ownership, Financial Distress}

Corresponding Author: Dongmin Kong

Email: kongdongmin@hotmail.com Copyright (C) 2021 by author(s)

This work is licensed under the Creative Commons Attribution International License (CC BY 4.0). http://creativecommons.org/licenses/ by/4.0/


\begin{abstract}
Purpose: The study aims to assess the potential impacts that the different attributes of corporate governance like the ownership structure and composition of the board on the probability of the listed firms in the UK falling into financial distress.

Approach/Methodology/Design: A quantitative methodology with a positivist paradigm and deductive reasoning were employed to collect data from $100 \mathrm{UK}$ based listed incorporation using FAME-A and BoardEx databases. Moreover, a longitudinal approach was used to collect data from 2014-2019 and sort it into a panel dataset, which was then analyzed using different statistical analysis approaches including pool ordinary least square regression analysis, Pearson's correlation, and descriptive statistics by using STATA statistical analysis tool.

Findings: The findings indicate that certain components of the composition of the board have a substantial effect on a company's probability to fall into financial distress; for instance, the board size, the board size, board independence, and the independence of the audit committee have a significant negative implication on the selected companies' probability to fall into financial distress. Similarly, some ownership structure components like institutional ownership and shareholder's ownership have significant negative implications on the firm's likelihood of financial distress, while audit committee size and the extent of ownership held by the management show an insignificant implication on the selected companies' probability to fall into financial distress.

Originality/value: The study also highlighted certain limitations and provided recommendations to future researchers to overcome these limitations in the future and reach more informed findings.
\end{abstract}

\section{INTRODUCTION}

Corporate governance refers to such policies and practices that help in the resolution of agency-related issues between the companies and their corresponding shareholders, which comprises of the internal system of controls, corporate decision making, and externalities like brand reputation, corporate value, and interaction with stakeholders (Ntim, 2017). There are two important characteristics or building blocks of corporate governance, which include the firm's ownership structure and board composition. The firm ownership structure refers to the extent of ownership represented by different types of shareholders in an organization, for 
instance, individual shareholders, institutional shareholders, shareholding or employees or the management, etc (Ganguli, 2016). Whereas the composition of the board of directors comprises education, recruitment, independence, demographics, leadership, and all other factors that define the operational parameters of a board and its corresponding contributions in the achievement of the organization's goals and objectives (Martín \& Herrero, 2018). Moreover, the term financial distress refers to such a condition of an organization, where it is unable to meet its financial obligations, i.e., when an organization is successively reporting negative earnings or unsatisfactory performance, then there is a significant likelihood for such organization to fall into a financial distress condition (Waqas \& Md-Rus, 2018).

There are lots of factors that can cause a firm to experience financial distress condition; however, the corporate governance structure and practices of an organization holds paramount status in either bringing prosperity and distress condition for a corporation (Udin et al., 2017); for instance, an aggressive attitude of the management, lack of proper oversight and supervision from the board of directors and an ineffective ownership structure of an organization can bring negative implications on its financial performance. Luqman et al., (2018) state that different characteristics of corporate governance like the ownership structure of a corporation play an important role during financial crises by ensuring a steady and easy flow of capital, which in turn, enable it to overcome the negative consequences of financial crises in an effective manner. It is also provided that the high prevalence of globalization caused increased competition among the businesses and therefore, it becomes highly essential for corporations to have a competitive board of directors, who have the required competencies and experiences to help the corporation stand out in the market. Such an advantage can be achieved by ensuring an effective composition of the board in terms of the selection of qualified, independent, and devoted members to the board of directors (Şener et al., 2011).

Furthermore, it is also provided that the increasing competition among the corporations due to globalization and the rapid emergence of disruptive technologies has opened up lots of new opportunities. However, at the same time, it causes significant stress among the low performing organizations to remain abreast in such a competitive environment and as a result, most of them failed to perform well and fall into financial distress condition, which is a matter of high concern for the researchers and policymakers (Keasey et al., 2014, and Kazemian et al., 2017). Therefore, the evaluation of the financial performance of organizations and the corresponding impacts that corporate governance brought on such financial performance remain a hot topic during the past few decades. However, it has been observed that the majority of studies are performed in the past on the possible implications of corporate governance on a firm's financial performance, but evaluation of its implications on the probability of a firm's falling into financial distress condition has been ignored (Shahwan, 2015; Salloum \& Azoury, 2012; Arora \& Sharma, 2016; Mardnly et al., 2018, and Roy, 2014). Therefore, this study particularly aims to evaluate the role of corporate governance, especially with reference to its two common qualities that are the arrangement of the board of directors and possession structure on the company's probability to fall into financial trouble condition, while focusing upon the UK based listed firms as a case study. For this purpose, the study attempts to answer how the main characteristics of corporate governance like the composition of the directors' board and ownership structure of the UK-based listed firms have an impact on their corresponding likelihood to fall into financial distress condition? This can be achieved by considering an evaluation of different dimensions of the ownership structure and composition of the board and how these dimensions contribute towards a firm's likelihood to fall into financial distress. 
Corporate governance refers to the processes, policies, customs, laws, institutional culture, and certain defined organizational procedures that guide the organizations in such a manner that they can perform effectively in terms of controlling, governing, and strategically directing the organizations to achieve their desired goals and objectives. Mostepaniuk, (2017) states that corporate governance sets the overall charter of an organization upon which the managers fulfill their responsibilities and duties within the confined boundaries assigned to them to bring positive and sustainable results to the shareholders through improved performance and profitability of an organization. Asensio-López et al., (2019) state that there are two important characteristics or dimensions of corporate governance, i.e., the ownership structure of an organization and the composition of its board of directors. These characteristics have been identified as highly determinantal for the success and growth of an organization because of their fundamental importance to create strategies that can help improve the organization's performance and profitability. Moreover, it has been observed that these characteristics become more important in the case of listed corporations where ownership and management are usually independent functions. Roy, (2016) states that corporate governance is usually governed by the agency and stewardship theories because in the case of listed corporations the management plays the role of an agent or steward to the owners/shareholders of the companies to whom they are responsible to take care of the vested interest given to them and work with utmost honesty to secure that interest with greater honesty and devotion.

Almudehki \& Zeitun (2012) performed an investigation on the possible association between performance and ownership structure of twenty Denmark-based listed firms and considered different types of ownership in their evaluation including foreign proprietorship, institutional ownership, managerial and internal ownership concentration, and board ownership. The authors found that the performance of the selected organizations was influenced by the board, foreign, and internal/managerial concentrated ownerships, while no relationship was identified with respect to the institutional ownership on the performance of corporations. It was further evaluated that such a relationship was identified due to the pressure imposed by agency theory on the management of these organizations because institutions usually prefer to invest in preference shares to get certain fixed returns of the corporation profit, and therefore, showed no influence on the corporate performance. Yusoff \& Alhaji (2012) states that the corporate governance literature has considered two main factors of the agency theory, which emphasize reducing the number of participants in a corporation to two main stakeholders that are management and the shareholders, and their interest should remain consistent and clear to one another. The author further explained that shareholders must always keep a strong control and supervision on the performance of the management through devising certain effective corporate governance practices because they are the sole caretakers of their interests. Panda and Leepsa, (2017) states that human nature comprises of certain hesitant and egoistic traits, which makes it difficult for them to compromise their interest over the interest of others, and therefore, with such limitations the agency theory usually fails to ensure the competitive performance of the management for securing the greater interest of the shareholders. Therefore, Abid et al. (2015) put forward the concept of stewardship theory in relation to corporate governance and its implications on a corporation's performance. The authors state that individuals who are vested with the role of implementation of good corporate governance practices are required to work as stewards of the organization and its stakeholders, they should have a fiduciary relationship with the organization and its shareholders. For instance, those charged with governance are usually responsible for the implementation of certain effective corporate governance practices and policies in an 
organization; therefore, they should always keep the interest of the organization and its shareholders at the top.

Subramanian, (2018) evaluated the Murugappa Group, which is 100-year-old family-owned incorporation and has successfully maintained a competitive position in the market until now. The author found that the family members as corporate stewards for the vested interest of the other internal and external stakeholders; for instance, the management always focus upon aligning its prevailing values with the perceived values through adaptation of the changing dynamics and trends of the market to remain competitive while disregarding their personal interests in such exercise. In another study conducted by Schillemans \& Bjurstrøm, (2019), it is found that trust and confidence are the two highly crucial factors for keeping a balance between the role of agency and stewardship prevailing in corporations. However, both of these factors can be achieved or established between the management and their corresponding shareholders through devotion and commitment standing for a longer period of time. Here it is also equally important to consider the ownership structure and underlying composition of the board of directors to ensure a sustainable balance between the stewards and agents to the owners of the company. For example, a board of directors having a higher number of independent non-executive directors as part of the board would exhibit strong controls over the performance of management and ultimately ensure a more secure and strong stewardship role in this regard.

Miglani et al. (2014) state that when certain characteristics of corporate governance are compromised by the organization, they increase their likelihood of falling into financial distress; for instance, the existence of dominant groups in the internal audit committee, or compromise over ownership by letting higher share to institutional shareholders or going for black holder's ownership. Baklouti et al., (2016) used binary logistic regression on sample data collected from the European commercial banks, especially such banks who were suffering from financial distress conditions. The authors found that ownership structure along with the composition of the board is identified as the two major characteristics of corporate governance that have a significant influence on the underlying agency relationship between the shareholders and managers of the selected banks. Furthermore, it was also found that lack of competitive board selection was identified as one of the major causes for the failure of these banks or their prevailing conditions of financial distress. Manzaneque et al., (2016) found a negative correlation between the size of a company's board of directors and its corresponding likelihood of financial distress. It was evaluated that corporations having an extensive board size have more likelihood to suffer from financial distress conditions as compared to such corporations that keep their board size confined and limited. Furthermore, it was also found that lack of diversity in the board of directors of corporations also negatively affects its financial performance and increases the likelihood of corporations falling into financial distress conditions. The authors also evaluated that the concentration of ownership in the selected Spanish corporations exhibited comparatively lower implications on its likelihood of financial distress.

Mangena et al., (2020) evaluated the proprietorship design and freedom of the individuals from the board of directors and the relating effect of these variables on the financial foundation's probability of financial misery. The authors collected data from about 35 Spanish-listed banks regarding their ownership structure and composition of the board. The study found that both the corporate governance characteristics have a significant contribution to a company's likelihood to fall into financial distress because the concentration of ownership determines a company's capability to conduct R\&D activities and enjoy better financial leverage in the market, while on the other hand independence of board plays a significant role in devising effective and sustainable strategies that are highly in line with 
both the stewardship and agency responsibilities of the management. Therefore, any inefficiency in any of the two characteristics can cause significant negative implications on a company's financial performance and ultimately cause it to fall into financial distress. Habib et al., (2018) conducted a systematic literature review of a huge pool of past studies to evaluate the underlying determinants and causes that make an organization fall into financial distress conditions. The authors found that determinants like audit and financial reporting, corporate governance practices, macroeconomic factors, and a firm's internal resources and capabilities depicts significant implications on the company's probability to fall into a distress circumstance while the firm-level corporate governance characteristics and attributes show an insignificant implication on its overall financial health. In another study conducted by Shahwan, (2015), an evaluation was performed on 86 non-monetary firms listed on the Egyptian stock exchange utilizing Tobin's Q to investigate the factors affecting the corporate performance of the selected organizations. The author used both stewardship and agency theories for evaluating the underlying implications of different factors on the corporate performance and growth prospects of the selected organizations. Furthermore, a corporate governance index was developed for assessing the role and implication of different CG characteristics on a firm's performance and corporate value, which includes the composition of the board of directors, ownership and management control, investors relationship management, transparency in the organization's reporting and disclosure frameworks and measures used for recognition of the rights of shareholders. The study found no optimistic relationship between the different characteristics of corporate governance with the underlying performance of the corporations. Besides, it was assessed that there is a huge negative connection between the company's probability of monetary misery and corporate governance exercises like the composition of the board and proprietorship concentration.

Shahwan \& Habib, (2020) found that the possession structure of a corporation has a significant impact on its corresponding performance because when a corporation has a steady and strong supply of capital, it enjoys a competitive position and financial leverage in the market. The authors also found that organizations having non-shareholding interests more than the interest of shareholding investors can exhibit greater chances to fall into a financial distress condition. Similarly, Orazalin et al., (2016) evaluated the possible implications of different dimensions of the corporate governance practices on the association's presentation and its corresponding probability to fall into monetary distress. The authors focus upon the ownership structure of corporations while considering different corporate governance-related theories and explored the ownership of organizations in terms of qualification of the chief executive officers, the extent of corporate disclosures made by a corporation, and the corporation's optimal ownership mix. The authors collected data from Russian based publicly traded banks, where data related to their financial performance and the corporate value was extracted from their financial statements, while the reports of the board of directors and annual corporate governance disclosures were used for obtaining data regarding different characteristics and dimensions of the corporate governance practices. The study used panel regression models and fixed-effect models for evaluation of the collected data, which revealed that ownership structure and qualification of the key management personnel have a critical effect on the performance and likelihood of firms to fall into monetary distress conditions. It is also evaluated that the corporate governance characteristics played a significant role in the recovery of banks and other financial institutions in the post-financial crises era, which is quite evident from the considerable structural and executive-level transformational changes executed by the selected banks during the post crises period. Hence, based upon the given theoretic review, the following hypotheses have been developed: 
H1: The composition of the board of directors has a significant implication on the Firms probability to monetary distress in the UK-based registered firms.

\section{H2: The ownership structure of the UK-based listed firms has an important implication on its likelihood of financial distress.}

\section{METHODOLOGY AND PROCEDURES}

The study has utilized a positivist worldview with deductive reasoning and quantitative methodology because the topic of the given study demands a highly objective evaluation, which can be conducted through adopting these methodologies. The positivist paradigm or research philosophy requires the researcher to use an objective approach for the collection of data and its subsequent analysis, which means that the researcher's involvement in the process of data collection and analysis was minimized. Furthermore, with the help of deductive reasoning, the researcher has first critically evaluated the past literature and developed certain theoretic perspectives about the possible association between the different attributes of corporate governance and the probability of a firm to fall into financial distress, which afterward guided the study in performing experimentation and analysis of the collected data to validate the theoretic perspectives formed. A quantitative methodology was used for the collection of archival data from 100 UK-based listed firms against all the dependent and independent variables of the study from the FAME-A and BoardEx databases, respectively. The study was based upon a longitudinal evaluation; therefore, a panel dataset was developed that contained data from 2014 to 2019. The debt to equity ratio was used as a proxy for a dependent variable that is financial distress, while for independent variable ownership structure proxies like institutional ownership, managerial ownership, and shareholder's ownership were used. Similarly, for the composition of the board proxies including board size, diversity among the board of directors, independence of the board members, independence of the audit committee, and size of the audit committee were used. Moreover, control variables like return on asset ratio, total assets, and debt to asset ratio were used to keep the outcomes consistent and precise. After collection of data and its appropriate sorting into an excel file, it was then analyzed through the statistical analysis tool STATA with the help of the given empirical model:

$$
\begin{aligned}
& F D=\boldsymbol{\beta}_{\mathbf{0}}+\boldsymbol{\beta}_{\mathbf{1}} R_{o A_{i t}}+\boldsymbol{\beta}_{\mathbf{2}} A u C S_{i t}+\boldsymbol{\beta}_{\mathbf{3}} \text { Insow }_{i t}+\boldsymbol{\beta}_{\mathbf{4}} T_{\text {T.Ast }}+\boldsymbol{\beta}_{\mathbf{5}} \text { Manow }_{i t}+\boldsymbol{\beta}_{\mathbf{6}} \text { BI }_{i t}+\boldsymbol{\beta}_{\mathbf{7}} \\
& D o A_{i t}+\boldsymbol{\beta}_{8} B D_{i t}+\boldsymbol{\beta}_{9} B S_{i t}+\boldsymbol{\beta}_{10} \text { Shaow }_{i t}+\boldsymbol{\beta}_{11} A u C I_{i t}+\mu_{i t}+\varepsilon_{i t}
\end{aligned}
$$

Where the dependent variable is represented by FD, while the control and independent variables are represented by ROA, AuCS, Insow, T.Ast, Manow, BI, DOA, BD. BS. Shaow, and $\mathrm{AuCI}$ as return on assets, audit committee size, institutional ownership, total assets, managerial ownership, board independence, debt to assets, board diversity, the board size, shareholder's ownership, and audit committee independence. Whereas the $\boldsymbol{\beta}$ values in the model are representing the coefficient of regression, $\mu_{\mathrm{it}}$ and $\varepsilon_{\text {it }}$ depict the error of estimate between and within the selected entities, respectively.

\section{RESULTS AND DISCUSSION}

The descriptive statistics show a varying number of observations against different proxies used, which depicts that an unbalanced panel dataset has been used for conducting the given analysis. Furthermore, it shows that out of 600 total observations, the dataset contained only 520 valid observations, which means that about 80 incomplete or invalid observations were omitted. Moreover, in terms of corporate governance characteristics, the mean value of shareholder's ownership is the highest, followed by institutional ownership, audit committee 
independence, and board independence. The mean value depicts the average of all these characteristics across the period from 2014 to 2019. Moreover, the standard deviation values against each variable show the degree of skewness in the distribution of observations. The highest standard deviation value is recorded against the total assets, which shows that the sample contained varying companies that have significantly varying total assets value across the given period of research. Likewise, the minimum and maximum values show the corresponding lower and upper threshold that has been recorded against the different proxies used for each variable of the study. The lowest minimum value is attributed to the return on assets, i.e., -64.08 , which depicts that the data has been collected from companies that have encountered financial distress from 2014 to 2019.

Table 1: Descriptive Statistics

\begin{tabular}{lccccc}
\hline \multicolumn{1}{c}{ Variable } & $\begin{array}{c}\text { No. } \\
\text { observations }\end{array}$ & Mean & Std. Dev & Min & Max \\
\hline Managerial ownership & 577 & 7.98 & 2.61 & 0 & 82.17 \\
Shareholder's ownership & 590 & 160.57 & 22.931 & .093 & 172.16 \\
Institutional ownership & 571 & 120.08 & 25.216 & .009 & 173.31 \\
Board independence & 600 & 61.39 & 10.909 & 11 & 93 \\
Audit Committee Independence & 580 & 87.93 & 7.182 & 22 & 97 \\
Board size & 520 & 7.15 & 2.003 & 2 & 17 \\
Board diversity & 536 & 20.14 & 11.063 & 0 & 69 \\
Audit committee size & 542 & 2.91 & 0.953 & 1 & 9 \\
Return on Asset Ratio & 553 & 3.871 & 11.089 & -64.081 & 42.459 \\
Debt to Asset ratio & 567 & 14.788 & 13.536 & 0 & 83.721 \\
Total Assets & 562 & 7871.85 & 27851.62 & 4.481 & 286170 \\
Financial Distress & 582 & 0.7313 & 0.8431 & 3.91 & 4.26 \\
\hline \multicolumn{1}{c}{ Valid N (Listwise) } & 520 & & & & \\
\hline
\end{tabular}

Table 2: POLS Regression Analysis

Panel variable: ID (unbalanced)

Time Variable: From 2014 to 19

\begin{tabular}{lrr} 
Source & \multicolumn{1}{l}{ SS } & \multicolumn{1}{c}{ df } \\
Model & 112.468 & 13 \\
Residual & 407.532 & 506 \\
Total & 520.000 & 519
\end{tabular}

Financial Distress

\begin{tabular}{|c|c|c|c|c|c|c|c|}
\hline Source & SS & df & MS & Number of obs & $s=$ & \multicolumn{2}{|l|}{520} \\
\hline Model & 112.468 & 13 & 0.928 & $\mathrm{~F}(13,506)$ & $=$ & \multicolumn{2}{|l|}{0.031} \\
\hline Residual & 407.532 & 506 & 0.761 & Prob $>$ F & $=$ & \multicolumn{2}{|l|}{0.0000} \\
\hline Total & 520.000 & 519 & & R-Squared & $=$ & \multicolumn{2}{|l|}{0.63} \\
\hline & & & & Adj R-Squared & $=$ & \multicolumn{2}{|l|}{0.54} \\
\hline & & & & Root MSE & $=$ & \multicolumn{2}{|l|}{0.781} \\
\hline \multirow[t]{13}{*}{ Financial Distress } & & Coef. & Std. Error & $\mathrm{T}$ & $\mathrm{P}<|\mathrm{t}|$ & \multicolumn{2}{|c|}{ [95\% Conf. Interval] } \\
\hline & BS & -0.031 & 0.031 & -0.718 & 0.413 & $0.071^{*}$ & 0.789 \\
\hline & $\mathrm{BI}$ & -0.003 & 0.016 & -0.230 & 0.028 & $0.312 *$ & 0.910 \\
\hline & $\mathrm{BD}$ & -0.006 & 0.013 & -0.682 & 0.053 & $0.041 *$ & 0.807 \\
\hline & AuSZ & -0.129 & 0.004 & -1.397 & 0.167 & $0.018 * *$ & 0.693 \\
\hline & $\mathrm{AuCI}$ & -0.002 & -0.051 & -0.231 & 0.012 & $0.261 *$ & 0.916 \\
\hline & Intow & -0.001 & 0.039 & 1.189 & 0.003 & $0.031 * *$ & 0.921 \\
\hline & Shaow & -0.001 & 0.021 & -0.536 & 0.031 & $0.293 * *$ & 0.939 \\
\hline & Manow & -0.105 & 0.041 & -1.273 & 0.301 & $0.391 * *$ & 0.817 \\
\hline & T.Ast. & -3.468 & 0.000 & -0.281 & 0.709 & $2.086^{*}$ & 4.671 \\
\hline & DoA & 0.003 & 0.001 & 2.487 & 0.019 & $0.041^{*}$ & 0.293 \\
\hline & RoA & -0.004 & 0.003 & -0.491 & 0.618 & $0.088^{*}$ & 0.516 \\
\hline & _cons & 1.318 & 0.364 & 1.931 & 0.451 & $0.035^{* *} *$ & 1.182 \\
\hline
\end{tabular}

Source: Authors 
Results of the pool least square regression analysis show that the $F$ value is 0.031 , which is less than the p-value of 0.05 at $95 \%$ confidence level, which depicts that the given regression model is statistically significant and therefore, can validate the results. The adjusted R-square of the given model is 0.54 , which means that the independent variable can cause a variation up to $54 \%$ in the dependent variable of the study that is financial distress. Moreover, results obtained against the individual proxies used for the two characteristics of corporate governance, i.e., the composition of the board and ownership structure of the enterprises shows that four out of five proxies used for the composition of the board including board size, board independence, audit committee independence, and board diversity shows a significant negative implication on the selected companies' probability to fall into financial distress. However, the only proxy used against the composition of the board is the audit committee size, which shows an insignificant negative implication on the selected companies' probability to fall into financial distress. Moreover, regarding the structure of ownership of the selected companies, institutional ownership shows positive implications on the selected companies' probability to fall into financial distress, and the shareholder's ownership shows a significant negative implication. However, managerial ownership shows an insignificant negative impact on the selected companies' probability to fall into financial distress. Furthermore, two out of the three control variables show significant implications on the selected companies' probability to fall into financial distress.

Table 3: Pearson's Correlation Analysis

\begin{tabular}{|c|c|c|c|c|c|c|c|c|c|c|c|c|}
\hline & $\mathrm{AuCS}$ & $\mathrm{BD}$ & BS & $\mathrm{AuCI}$ & BI & Manow & Insow & Shaow & DoA & RoA & T.Ast. & FD \\
\hline $\begin{array}{l}\text { Audit Committee } \\
\text { Size }\end{array}$ & 1 & & & & & & & & & & & \\
\hline Board Diversity & $.106^{* *}$ & 1 & & & & & & & & & & \\
\hline Board Size & $.213 * *$ & $.139 * *$ & 1 & & & & & & & & & \\
\hline $\begin{array}{l}\text { Audit Committee } \\
\text { Independence }\end{array}$ & $.361 * *$ & $.016^{* * *}$ & $.093^{*}$ & 1 & & & & & & & & \\
\hline $\begin{array}{l}\text { Board } \\
\text { Independence }\end{array}$ & $.039 *$ & $-.063 * *$ & $-.037 * *$ & $-.027 *$ & 1 & & & & & & & \\
\hline $\begin{array}{l}\text { Managerial } \\
\text { Ownership }\end{array}$ & $-.146^{* *}$ & $-.027 *$ & $-.182 * *$ & $.049^{*}$ & $-.051 *$ & 1 & & & & & & \\
\hline $\begin{array}{l}\text { Institutional } \\
\text { Ownership }\end{array}$ & $.047^{*}$ & $.128 * *$ & $.162 * *$ & $.076^{*}$ & $.003 *$ & $-.031 * *$ & 1 & & & & & \\
\hline $\begin{array}{l}\text { Shareholder's } \\
\text { Ownership }\end{array}$ & $.039 * *$ & $.004 *$ & $-.028 * *$ & $.039^{*}$ & $.038^{*}$ & $-.049 * *$ & $.09 *$ & 1 & & & & \\
\hline Debt to Asset & $.408 * *$ & $.362 * *$ & $.139 * *$ & $.041^{*}$ & $.029 *$ & $-.057 * *$ & $.016^{*}$ & $.061 *$ & 1 & & & \\
\hline Return on Assets & $.213 * *$ & $.182 * *$ & $.187 * *$ & $.046^{*}$ & $-.037 *$ & $-.026^{*}$ & $-.032 *$ & $-.019 *$ & $\begin{array}{l}.11 \\
0 * *\end{array}$ & 1 & & \\
\hline Total Assets & $.121 * *$ & $.039 * *$ & $.231 * *$ & $.131^{*}$ & $-.031 *$ & $-.019 * *$ & $\begin{array}{l}.019 * \\
*\end{array}$ & $-.037 *$ & $\begin{array}{l}- \\
.00 \\
7 * *\end{array}$ & $\begin{array}{l}- \\
.021 * \\
*\end{array}$ & 1 & \\
\hline Financial distress & $.283^{* *}$ & $-.009^{*}$ & $-.007 * *$ & $.001^{*}$ & $-.079^{*}$ & $-.081 * *$ & $-.007 *$ & $.031 * *$ & $\begin{array}{l}.03 \\
1 * *\end{array}$ & $\begin{array}{l}.026^{*} \\
*\end{array}$ & $.271^{*}$ & 1 \\
\hline
\end{tabular}

**. Correlation is significant at the 0.01 level (2-tailed).

*. Correlation is significant at the 0.05 level (2-tailed). 
Results of Pearson's correlation analysis shows that three out of five proxies used for determining the possible implications of the composition of the board on the selected companies' probability to fall into financial distress has a significant impact, whereas board diversity and board size shows a negative correlation with the selected companies' probability to fall into financial distress, while the audit committee size gives surprisingly different results from the regression analysis and shows a positive correlation with the selected companies' probability to fall into financial distress. It means that an increase in the board size and diversity would cause a corresponding reduction in the selected companies' probability to fall into financial distress, while an increase in audit committee independence would increase the chances of the selected companies' probability to fall into financial distress. The relationship is significant at a confidence level of 0.01 and 0.05 , respectively. Furthermore, the board independence shows a surprisingly insignificant correlation with the selected companies' probability to fall into financial distress, i.e., insignificant at both the confidence level of 0.01 and 0.05 . Moreover, in terms of the ownership structure, the results of the Pearson correlation analysis are consistent with that of the POLS regression analysis. The institutional and shareholder ownership shows a significant relationship, while the managerial ownership shows an insignificant relationship with the selected companies' probability to fall into financial distress at a confidence level of 0.01 and 0.05 . Furthermore, the DoA and RoA show a significant positive relationship with the firm's likelihood of financial distress with a coefficient of correlation of 0.031 each at a confidence level of $95 \%$.

\section{Discussion}

Results obtained from statistical evaluation of the collected data against different proxies used for measuring the dependent and independent variables of the study show that four out of five variables used against the composition of the board show significant implications on a company's probability to fall into financial distress. Similarly, two out of three proxies used for measuring the ownership structure show a huge relationship with the selected companies' probability to fall into financial distress. It is discovered that audit board size and administrative proprietorship show an immaterial effect on the selected companies' probability to fall into financial distress. The findings of this study with respect to board size and board diversity are supported by the study of Şener et al., (2011), who found that the size of the board of directors and its corresponding diversity has a significant positive impact on a company's performance because having a diverse board of directors, who are rich in numbers and expertise allows a company to get benefit from a highly competitive and enriched experience. In another study conducted by Mangena (2020), it is found that the Spanish listed firms, which have a comparatively more diverse and competent board in terms of highly qualified and experienced members exhibited strong financial positions and rare chances of getting into financial distress. The authors also evaluated that firms having more shares from the ordinary and institutional shareholders in their ownership structure have less likelihood to fall into financial distress.

The findings of the study conducted by Shahwan (2015) are also in line with the findings of the current study; for instance, the author evaluated that companies usually fall into financial distress due to a lack of resources and competent management. The author found that most of the Egyptian listed corporations fell into financial distress due to a lack of an appropriate number of competent members on their board of directors or capital resources to cope with the market competition. Baklouti, et.al, (2016) found that effective corporate governance practices are those that help an organization to build a competitive and balanced ownership structure, which is capable of supporting it at times of need, especially when the firm is wishing to initiate any new project or research and development activity. Udin, et al., (2017) found that managerial ownership has often proven ineffective in improving an organization's 
exhibition and financial position. The authors also evaluated that in managerial ownership the concept of stewardship and agency is not present, which causes careless behavior among the management that leads to ineffective performance and strategic decisions, which in turn causes an organization to fall into monetary distress. The findings of this study are in accordance with the discoveries of the given investigation regarding administrative proprietorship and its implications on a company's probability to fall into financial distress. Furthermore, the study of Mardnly, et, al., (2018) found that corporate governance plays an important role in improving an organization's performance and market share; however, it is critically significant to manage the corporate governance practices and characteristics in the right direction. The authors also found that the composition of the board of directors and ownership structure plays an important role in building a strong corporate culture in an organization due to the underlying stewards and agents' relationship between the two components.

\section{CONCLUSIONAND SUGGESTION}

The study was planned to assess the effect of corporate administration exercises on the UKbased registered companies' probability to fall into financial distress. After conducting a critical evaluation of the past literature and empirical analysis of the data collected from 100 UK based listed firms, the study found that four out of five components involved in the composition of the board of directors of the selected firms shows a significant impact on their probability to fall into financial distress. Similarly, it is additionally found that two out of three components of the selected firm's ownership structure have a huge relationship with the selected companies' probability to fall into financial distress. Only two components of the corporate governance practices, audit panel size and the extent of ownership, are held by the management showed an insignificant relationship with the selected companies' probability to fall into financial distress. The study also has certain limitations; for instance, it has been conducted on the UK-based listed firms only. Therefore, the generalization of its findings would be less effective in the future, especially concerning conducting studies in other countries that have different corporate culture than that of the UK. Furthermore, the findings of the study might have been impaired to some extent due to the use of unbalanced data for analysis. Similarly, the corporate governance characteristics like the composition of the board are relatively qualitative in nature and therefore, more informed findings would have obtained, if the study was conducted through a mixed-method approach. Therefore, it is recommended to future researchers to use a broader sample base preferably based upon more than one country, so that more informed evaluations could be made. Similarly, future researchers should consider conducting evaluation using a mixed-method or purely qualitative study approach to get more informed findings regarding the subject matter of the study.

\section{Conflict of Interest}

The authors declare no conflict of interest.

\section{Funding}

No funds received for conducting this study.

\section{References}

Abid, G., Khan, B., Rafiq, Z., \& Ahmed, A. (2015). Theoretical Perspectives of Corporate Governance. Bulletin Of Business And Economics (BBE), 3(4), 166-175. 
Almudehki, N., \& Zeitun, R. (2012). Ownership Structure and Corporate Performance: Evidence from Qatar. SSRN Electronic Journal. https://doi.org/10.2139/ssrn.2154289

Arora, A., \& Sharma, C. (2016). Corporate governance and firm performance in developing countries: evidence from India. Corporate Governance, 16(2), 420-436. https://doi.org/10.1108/cg-01-2016-0018

Asensio-López, D., Cabeza-García, L., \& González-Álvarez, N. (2019). Corporate governance and innovation: a theoretical review. European Journal Of Management And Business Economics, 28(3), 266-284. https://doi.org/10.1108/ejmbe-05-2018-0056

Baklouti, N., Affes, H., \& Gautier, F. (2016). Corporate Governance and Financial Distress of European Commercial Banks. Journal Of Business Studies, 7(3), 13-37. https://doi.org/10.1007/s40804-020-00201-z

Ganguli, S. (2016). Board Composition, Ownership Structure and Firm Performance: New Indian Evidence in a Unique Regulatory Environment. SSRN Electronic Journal. https://doi.org/10.2139/ssrn.2746773

García Martín, C., \& Herrero, B. (2018). Boards of directors: composition and effects on the performance of the firm. Economic Research-Ekonomska Istraživanja, 31(1), 10151041. https://doi.org/10.1080/1331677x.2018.1436454

Habib, A., Costa, M., Huang, H., Bhuiyan, M., \& Sun, L. (2018). Determinants and consequences of financial distress: review of the empirical literature. Accounting \& Finance, 60(S1), 1023-1075. https://doi.org/10.1111/acfi.12400

Kazemian, S., Shauri, N., Sanusi, Z., Kamaluddin, A., \& Shuhidan, S. (2017). Monitoring mechanisms and financial distress of public listed companies in Malaysia. Journal of International Studies, 10(1), 92-109. https://doi.org/10.14254/2071-8330.2017/10-1/6

Keasey, K., Pindado, J., \& Rodrigues, L. (2014). The determinants of the costs of financial distress in SMEs. International Small Business Journal: Researching Entrepreneurship, 33(8), 862-881. https://doi.org/10.1177/0266242614529317

luqman, R., Ul hassan, M., Tabasum, S., Khakwani, M., \& Irshad, S. (2018). Probability of financial distress and proposed adoption of corporate governance structures: Evidence from Pakistan. Cogent Business \& Management, 5(1), 1492869. https://doi.org/10.1080/23311975.2018.1492869

Mangena, M., Priego, A., \& Manzaneque, M. (2020). Bank power, block ownership, boards and financial distress likelihood: An investigation of Spanish listed firms. Journal of Corporate Finance, 64, 101636. https://doi.org/10.1016/j.jcorpfin.2020.101636

Manzaneque, M., Priego, A., \& Merino, E. (2016). Corporate governance effect on financial distress likelihood: Evidence from Spain. Revista De Contabilidad, 19(1), 111-121. https://doi.org/10.1016/i.rcsar.2015.04.001

Mardnly, Z., Mouselli, S., \& Abdulraouf, R. (2018). Corporate governance and firm performance: an empirical evidence from Syria. International Journal Of Islamic And Middle Eastern Finance And Management, 11(4), 591-607. https://doi.org/10.1108/imefm-05-2017-0107

Miglani, S., Ahmed, K., \& Henry, D. (2015). Voluntary corporate governance structure and financial distress: Evidence from Australia. Journal Of Contemporary Accounting \& Economics, 11(1), 18-30. https://doi.org/10.1016/j.jcae.2014.12.005

Mostepaniuk, A. (2017). Corporate Governance. Corporate Governance And Strategic Decision Making. https://doi.org/10.5772/intechopen.69704

Ntim, C. (2017). Defining Corporate Governance: Shareholder Versus Stakeholder Models. Global Encyclopedia Of Public Administration, Public Policy, And Governance, 1-9. https://doi.org/10.1007/978-3-319-31816-5 3132-1

Orazalin, N., Mahmood, M., \& Jung Lee, K. (2016). Corporate governance, financial crises and bank performance: lessons from top Russian banks. Corporate Governance: The 
International Journal Of Business In Society, 16(5), 798-814. https://doi.org/10.1108/cg-10-2015-0145

Panda, B., \& Leepsa, N. (2017). Agency theory: Review of Theory and Evidence on Problems and Perspectives. Indian Journal Of Corporate Governance, 10(1), 74-95. https://doi.org/10.1177/0974686217701467

Roy, A. (2014). Corporate Governance and Firm Performance: An Exploratory Analysis of Indian Listed Companies. Jindal Journal Of Business Research,3(1-2), 93-120. https://doi.org/10.1177/2278682116629537

Roy, A. (2016). Corporate Governance and Firm Performance: A Study of Indian Listed Firms. Metamorphosis: A Journal Of Management Research, 15(1), 31-46. https://doi.org/10.1177/0972622516629032

Salloum, C., \& Azoury, N. (2012). Corporate governance and firms in financial distress: evidence from a Middle Eastern country. International Journal Of Business Governance And Ethics, 7(1), 1. https://doi.org/10.1504/ijbge.2012.046102

Schillemans, T., \& Bjurstrøm, K. (2019). Trust and verification: balancing agency and stewardship theory in the governance of agencies. International Public Management Journal, 23(5), 650-676. https://doi.org/10.1080/10967494.2018.1553807

Şener, İ., Varoğlu, A., \& Aren, S. (2011). Board Composition and Organizational Performance: Environmental Characteristics Matter. Procedia - Social And Behavioral Sciences, 24, 1481-1493. https://doi.org/10.1016/j.sbspro.2011.09.130

Shahwan, T. (2015). The effects of corporate governance on financial performance and financial distress: evidence from Egypt. Corporate Governance, 15(5), 641-662. https://doi.org/10.1108/cg-11-2014-0140

Shahwan, T. (2015). The effects of corporate governance on financial performance and financial distress: evidence from Egypt. Corporate Governance, 15(5), 641-662. https://doi.org/10.1108/cg-11-2014-0140

Shahwan, T., \& Habib, A. (2020). Does the efficiency of corporate governance and intellectual capital affect a firm's financial distress? Evidence from Egypt. Journal Of Intellectual Capital, 21(3), 403-430. https://doi.org/10.1108/jic-06-2019-0143

Subramanian, S. (2018). Stewardship Theory of Corporate Governance and Value System: The Case of a Family-owned Business Group in India. Indian Journal Of Corporate Governance, 11(1), 88-102. https://doi.org/10.1177/0974686218776026

Udin, S., Khan, M., \& Javid, A. (2017). The effects of ownership structure on likelihood of financial distress: an empirical evidence. Corporate Governance: The International Journal Of Business In Society, 17(4), 589-612. https://doi.org/10.1108/cg-03-2016-0067

Waqas, H., \& Md-Rus, R. (2018). Predicting financial distress: Importance of accounting and firm-specific market variables for Pakistan's listed firms. Cogent Economics \& Finance, 6(1), 1545739. https://doi.org/10.1080/23322039.2018.1545739

Yusoff, W., \& Alhaji, I. (2012). Insight of Corporate Governance Theories. Journal Of Business \& Management, 1(1), 52-63. https://doi.org/10.12735/jbm.v1i1p52 